\title{
Physicochemical, Microbiological, Antioxidant and Sensory Characteristics of "Aguamiel” Microencapsulated by Spray Drying
}

\author{
Castro-Díaz, S. ${ }^{1}$, Cid-Ortega, S. $^{2}$ \& Guerrero-Beltrán, J. A. ${ }^{3}$ \\ ${ }^{1}$ Programa Educativo de Ingeniería en Procesos Bioalimentarios. Universidad Tecnológica de Tecamachalco. \\ Tecamachalco, Puebla 75483, Mexico \\ ${ }^{2}$ Programa Educativo de Ingeniería en Procesos Alimentarios. Universidad Tecnológica de Izúcar de Matamoros. \\ Izúcar de Matamoros, Puebla 74420, Mexico \\ ${ }^{3}$ Departamento de Ingeniería Química y Alimentos. Universidad de las Américas Puebla. Cholula, Puebla 72810, \\ Mexico \\ Correspondence: José Angel Guerrero-Beltrán, Departamento de Ingeniería Química y Alimentos, Universidad \\ de las Américas Puebla, Cholula, Puebla, 72810, Mexico. E-mail: joseangel150@ hotmail.com
}

Received: June 16, 2017

Accepted: July 6, 2017 Online Published: August 5, 2017

doi:10.5539/jfr.v6n5p11

URL: https://doi.org/10.5539/jfr.v6n5p11

\begin{abstract}
The aim of this work was to obtain powders of "aguamiel" (AM) (from Agave salmiana) by spray drying using maltodextrin (MD) and Arabic gum (AG) as encapsulates. Three microencapsulated powders were obtained: Powder $1\left(\mathrm{P}_{1}, \mathrm{AM} / \mathrm{MD}\right)$, Powder $2\left(\mathrm{P}_{2}, \mathrm{AM} / \mathrm{AG} / \mathrm{MD}\right.$; AG:MD, 3:1) and Powder 3 ( $\mathrm{P}_{3}, \mathrm{AM} / \mathrm{MD} / \mathrm{AG} ; \mathrm{AG}: \mathrm{MD}$, 1:3) from solutions with $20 \%(\mathrm{w} / \mathrm{w})$ of solutes. Powders were evaluated according to their physicochemical, antioxidant, microbiological and sensory characteristics. Powders had averages of moisture content of $2.55 \pm$ $0.24 \%$, water activity of $0.34 \pm 0.02$, and particle size of $29.84 \pm 1.4 \mu \mathrm{m}$. It was observed that the higher the concentration of Arabic gum, the darker the powders. The physicochemical and color properties of the rehydrated powders were similar to those of fresh "aguamiel". The microbial load, during 95 days of storage, indicated no significant changes $(p>0.05$ ) between the initial and final values in the three powders; the highest microbial load was observed in powder $\mathrm{P}_{3}\left(6.6 \times 10^{3} \mathrm{CFU} / \mathrm{mL}\right.$ and $5.9 \times 10^{3} \mathrm{CFU} / \mathrm{mL}$, initial and final loads, respectively). The content of phenolics in powders $\mathrm{P}_{1}, \mathrm{P}_{2}$ and $\mathrm{P}_{3}$ during storage were $212.40 \pm 68.22,350.51 \pm$ 145.00 , and $266.25 \pm 89.93 \mathrm{mg}$ Gallic acid equivalents $/ 100 \mathrm{~g}$, respectively; the antioxidant capacity was $1,207.13 \pm 109.64,1,172.17 \pm 145.80$, and $1,183.34 \pm 65.17 \mathrm{mg}$ Trolox equivalents $/ 100 \mathrm{~g}$, respectively. According to the sensory evaluation of the rehydrated powders, the better acceptance was obtained with the $\mathrm{P}_{3}$ powder, with better physicochemical and sensorial characteristics.
\end{abstract}

Keywords: aguamiel, Agave salmiana, spray drying, Arabic gum, maltodextrin, antioxidant properties

\section{Introduction}

The Agave spp. is known by the common name of "maguey", "pita" or "agave". It belongs to the Asparagaceae family and Agavoideae subfamily. The man has obtained different products from agave: alcoholic beverages (e.g. tequila, mezcal), fructose syrups, handicrafts and "aguamiel", this last one has been, of all byproducts, the least technologically exploited (Muñíz-Márquez, Rodríguez-Jasso, Rodríguez-Herrera, Contreras-Esquivel, \& Aguilar-González, 2013).

There is a great diversity of agaves for producing "aguamiel" and then "pulque" (it is a light alcoholic thick beverage). The species A. mapisaga, A. atrovirens, and A. salmiana may produce "aguamiel" of different qualities; they can be found in Mexico (Valley of Mexico), Tlaxcala, Hidalgo, and Puebla states (Alfaro, Legaria, \& Rodríguez, 2007); however, as a result of rural growth and the increased land use, natural ecosystems have experienced irreversible deterioration (Martínez-Morales, \& Meyer, 1985). It is important to mention that Agave salmiana is the ancestor of all species of broad-leaf agaves and is one of the two most widely used agaves to produce "aguamiel" in Mexico (Parra, Del Villar, \& Prieto, 2010).

"Aguamiel" is a natural soft drink related closely to the history of Mexico. In pre-Hispanic times, it was the most consumed "candy" named "tlitica-necutli" in Nahuatl language. The Aztecs used aguamiel as an energetic beverage and as a remedy to cure different diseases (Ortiz-Basurto et al. (2008). 
"Aguamiel" is the liquid (sap) exuded from the core (the stem and leaf bases, "cogollo", "piña", "bowl" or "cajete") and part of the flesh from the core of the agave. The "aguamiel" is exuded over a period of 3 to 6 months (Muñíz-Marquez et al., 2013); however, depending on the robustness of the plant (9 to 12 years to be mature), the period of obtaining "aguamiel" can be extended up to 8 months producing a total of 500 to 1000 liters of "aguamiel" throughout its whole life (Guillot \& Deer, 2008).

"Aguamiel" is a light turbid yellowish liquid with herbaceous (green grass) flavor. It is made up of water, fructose, glucose and sucrose as well as its own flavor chemical compounds; it can be acidic or slightly alkaline in taste. Aguamiel is obtained from specific agaves to produce "pulque". Ortiz-Basurto et al. (2008) reported that aguamiel from Agave mapisaga contains $8.62 \%$ of sugars, $0.86 \%$ corresponds to fructo-oligosaccharides (FOS), considered prebiotics.

The process of fermentation of "aguamiel" can start in the maguey "bowl" ("cogollo") spontaneously (Shmit et al., 2014) due to autochthonous bacteria, depending on the temperature in the environment. In the "bowl", natural microorganisms present in the exudation environment, such as yeasts, lactic acid bacteria, dextran producing bacteria and ethanolic bacteria, as well as putrefactive bacteria from the environment, can ferment the "aguamiel" (Cenvantes-Contreras, 2008). Fermentation can proceed in a very short period (Lappe-Oliveras et al., 2008, Rodríguez-Huezo et al., 2007; Estrada-Godinal et al., 2001).

An alternative to provide "aguamiel" with greater stability is obtaining microencapsulated powders by spray drying. Microencapsulation is the "packaging" technology of solids, liquids or gases in small sealed capsules that can release their contents in very small quantities controlled under specific conditions (Uddin, Hawlader, \& Zhu, 2001). This technology has been widely accepted for encapsulating fruit and vegetable juices to remove the high amount of water from the product and to form a more microbiologically stable product (powder), notably increasing its stability and shelf life (Pérez-Alonso et al., 2015). Previous studies in microencapsulation of liquids indicate that mixing sugars with maltodextrin improves dehydration properties during drying and storage stability (Li, Roos, \& Miao, 2017). Arabic gum on the other hand is considered one of the best encapsulants for a wide variety of food materials (Bernstein \& Zapata, 2015).

The objective of this work was to evaluate the physicochemical, antioxidant and microbiological characteristics of spray dried "aguamiel" mixed with maltodextrin and Arabic gum.

\section{Materials and Methods}

\subsection{Materials}

Aguamiel $\left(11.5^{\circ} \mathrm{Bx} ; 11.5 \% \mathrm{w} / \mathrm{w}\right)$ obtained from Agave salmiana maguey, cultivated in Lomas de Romero, Tecamachalco, Puebla, Mexico, was used. As soon as aguamiel was collected (in May for two days in the morning and in the afternoon) from the agave core or "bowl", it was cooled down as quickly as possible, with an ice-water mixture $\left(4 \pm 1^{\circ} \mathrm{C}\right)$ surrounding the aguamiel containers, to stop fermentation.

\section{2 "Aguamiel”-gums Blends}

Arabic gum (AG) from Acacia senegal and maltodextrin (MD) of $10 \mathrm{DE}$ (equivalents of dextrose) (Industrias Alimenticias FABPSA®, Mexico City, Mexico) were used. Three mixtures of aguamiel with AG and MD were prepared to obtain powders: a) powder $\mathrm{P}_{1}$, AM/MD, b) powder $\mathrm{P}_{2}$, AM/AG/MD (AG:MD, 3:1) and c) powder $\mathrm{P}_{3}$, AM/AG/MD (AG:MD, 1:3) to obtain $20 \%(\mathrm{w} / \mathrm{w}$ ) solutions. Calculus were performed to add the amount of gums (alone or blends) to the "aguamiel" $\left(11.5^{\circ} \mathrm{Bx}\right)$ to obtain $20^{\circ} \mathrm{Bx}$ (total soluble solids, TSS) solutions. All blends were homogenized and then passed through a sieve No. $80(0.177 \mathrm{~mm})$ to remove lumps and obtain a homogenous dispersion or solution. Powders were obtained in duplicate.

\subsection{Spray Drying}

A spray dryer of the brand GEA Niro S/A (Soeborg, Denmark), was used. Inlet and outlet air temperatures of $162.7 \pm 2.5^{\circ} \mathrm{C}$, and $90 \pm 2{ }^{\circ} \mathrm{C}$ were used, respectively. The feed flow of solutions was $1.068 \mathrm{~mL} / \mathrm{s}$. The equipment was stabilized with distilled water and samples were then spray dried. Powders obtained were weighed and placed in plastic jars covered with aluminum foil and stored at $24 \pm 1^{\circ} \mathrm{C}$ to allow them to reach an equilibrium in moisture content before analyzing their physicochemical, antioxidant and microbiological characteristics.

\subsection{Rehydrated Powders}

To obtain the rehydrated aguamiel from powders, a ratio of 11:89 by weight of powder and purified water were perfectly mixed. The rehydrated aguamiel was analyzed for their physicochemical, microbiological, antioxidant, and sensory characteristics. 


\subsection{Physicochemical Characteristics}

\subsubsection{Moisture Content}

It was determined using the 934.06 AOAC (Association of Official Agricultural Chemists [AOAC], 2000) method. An Ecoshel HV-50 vacuum oven (Ecoshel Technology Ltd, Mc Allen, Texas, USA) was used. Drying was carried out for 6 hours at $70 \pm 1^{\circ} \mathrm{C}$ and at a vacuum of $100 \mathrm{mmHg}$.

\subsubsection{Total Soluble Solids}

It was used an Atago hand refractometer model Master-M (Atago Co. Ltd., Tokyo, Japan). The readings were corrected at $20^{\circ} \mathrm{C}$ using the AOAC (1995) reference tables.

\section{$2.5 .3 \mathrm{pH}$}

It was determined according to the Mexican Standard Norm number NMX-F-317-S-1978 (Dirección General de Normas [DGN], 1978a). $20 \mathrm{~mL}$ of fresh or rehydrated "aguamiel" were used. The electrode of an Orion potentiometer model 420A (Orion Research Inc., Jacksonville, FL, USA), calibrated with pH 4, 7 and 10 buffer solutions, was introduced directly into the sample.

\subsubsection{Acidity}

It was determined according to method 942.15 AOAC (2000) method. Five milliliters of "aguamiel" $\left(V_{a}\right)$ were placed in a $125 \mathrm{~mL}$ conical flask, 5 drops of phenolphthalein added. The mixture was titrated with $0.1 \mathrm{~N}$ sodium hydroxide until a pale pink color appeared. Acidity was calculated using the next equation:

$$
\operatorname{Acidity}(\%)=\frac{V_{\mathrm{NaOH}} * N_{\mathrm{NaOH}} * 0.09}{V_{a}} * 100
$$

where $V_{\mathrm{NaOH}}(\mathrm{g} / \mathrm{mL})$ is the volume of sodium hydroxide, $N_{\mathrm{NaOH}}$ is the normality of sodium hydroxide and 0.09 miliequivalent of lactic acid.

\subsubsection{Water Activity}

It was measured using an AQUALAB hygrometer (Decagon Instruments, Pullman, WA, USA) at $26^{\circ} \mathrm{C}$. The amount of sample used for "aguamiel" and powder was $1 \mathrm{~mL}$ and $0.5 \mathrm{~g}$, respectively. Samples were placed in the sample container and then this in the compartment of the equipment. The water activity was recorded when the equilibrium was reached in the equipment.

\subsubsection{Density}

The density of fresh and rehydrated aguamiel was determined according to the 962.37 AOAC (1995) method. Ten-mL pycnometers previously placed at constant weight were used. The empty pycnometer $\left(P_{e}\right)$, the pycnometer with distilled water $\left(P_{w}\right)$ and the pycnometer with sample $\left(P_{s}\right)$ were weighed after being equilibrated at $25^{\circ} \mathrm{C}$. Density was calculated according to the next equation:

$$
\rho=\left[\frac{P_{s}-P_{e}}{P_{w}-P_{e}}\right] * \rho_{H_{2} O}
$$

where $\rho_{\mathrm{H}_{2} \mathrm{O}}(\mathrm{g} / \mathrm{mL})$ is the density of water at $25^{\circ} \mathrm{C}$.

\subsubsection{Viscosity}

It was determined using a Cannon-Fenske viscometer model 350-160I (Cannon Instrument Company, College, PA, USA). The flow of the aguamiel $(6.6 \mathrm{~mL})$ was measured keeping the instrument immersed in water al $40^{\circ} \mathrm{C}$. The viscosity was determined using the following equations recommended by the Cannon Instrument Co.:

$$
\begin{aligned}
& \mu_{c}=C^{*} t \\
& \mu=\rho_{s} * \mu_{c}
\end{aligned}
$$

where $\mu$ is the dynamic viscosity (cP), $\rho_{s}$ is the density of the solution $\left(\mathrm{g} / \mathrm{cm}^{3}\right), \mu_{c}$ is the kinematic viscosity (cSt), $C$ is the constant of the viscometer at $40^{\circ} \mathrm{C}(0.4754 \mathrm{cSt} / \mathrm{s})$, and $t$ is the time (s). 


\subsubsection{Ash}

It was analyzed according to the Mexican Standard Norm number NMX-F-066-S-1978 (DGN, 1978b). A FELISA muffle furnace model FE369 (Zapopan, Jalisco, Mexico) was used. Samples were placed in porcelain crucibles and calcined at $500^{\circ} \mathrm{C}$ for 7 hours.

\subsubsection{Color}

A Colorgard system 05 colorimeter (BYK-Gardner Inc., Silver Spring, Maryland, USA) was used. The color determination was performed by pre-calibrating the equipment with a black mosaic (for transmittance mode). To measure the color of aguamiel, a $3 \mathrm{~mL}$ ( $2 \mathrm{~mm}$ thick) quartz cell (Konica Minolta Sensing Americas Inc., Ramsey, NJ, USA) was used. The $L^{*}$ (lightness), $a^{*}$ (red to green) and $b^{*}$ (yellow to blue) color parameters were measured on the CIELab scale. From these data the purity $(C=$ saturation) and the hue $(\mathrm{H})$ of the color were calculated:

$$
\begin{gathered}
C=\left(a^{* 2}+b^{* 2}\right)^{1 / 2} \\
H=\tan ^{-1}\left(b^{*} / a^{*}\right)
\end{gathered}
$$

\subsubsection{Average Particle Size}

It was measured using a Microtac S3500 particle size analyzer (Microtac Inc., Largo, FL, USA) with laser light diffraction in a measurement range of 0.25 to $2800 \mu \mathrm{m}$. The analysis was performed using approximately $20 \mathrm{mg}$ of the spray dried powders. The particle size distribution and accumulative retained weight curves were obtained as well as the mean diameter, $\mathrm{d}_{50}$ (Guerrero-Beltrán, Jiménez-Munguía, Welti-Chanes, \& Barbosa-Cánovas, 2009).

\subsection{Microbiological Analysis}

\subsubsection{Aerobic Mesophilic Bacteria (AMB)}

Serial dilutions of aguamiel with peptone water (Becton Dickinson of Mexico S.A. of C.V., Mexico) were made. The AMB counts were performed by the standard method using bacteriological agar (Becton Dickinson of Mexico S.A. of CV., Mexico). Petri dishes were incubated at $35 \pm 2{ }^{\circ} \mathrm{C}$ and colony units counted in a period between 24 and $48 \mathrm{~h}$ of incubation.

\subsubsection{Molds Plus Yeasts (MY)}

Serial dilutions of aguamiel were done with peptone water (Becton Dickinson of Mexico S.A. of C.V., Mexico). The MY counts were performed by the standard method using potato dextrose agar (Becton Dickinson of Mexico S.A. of CV., Mexico). Petri dishes were incubated at $25 \pm 2{ }^{\circ} \mathrm{C}$ and colony units counted after 5 days of incubation.

\subsection{Antioxidant Characteristics}

\subsubsection{Total Phenolics Content (TPC)}

It was determined by the Folin-Ciocalteu method (Singleton \& Rossi, 1965) with some modifications. Into test tubes (covered with aluminum foil), $3 \mathrm{~mL}$ of distilled water, $700 \mu \mathrm{L}$ of reconstituted "aguamiel" solution (200 $\mathrm{mg}$ of powder dissolved and made up to $10 \mathrm{~mL}$ with distilled water) and $250 \mu \mathrm{L}$ of Folin-Ciocalteu reagent were placed. This mixture was stirred and after 30 seconds $750 \mu \mathrm{L}$ of $20 \% \mathrm{Na}_{2} \mathrm{CO}_{3}$ was added, made up to $5 \mathrm{~mL}$ with distilled water, totally mixed and allowed to stand for 2 hours at room temperature $\left(22 \pm 1^{\circ} \mathrm{C}\right)$ in the dark. The absorbance was then measured at $765 \mathrm{~nm}$ using a Cary $100 \mathrm{UV}$-Visible spectrophotometer (Varian Inc., Palo Alto, CA, USA). Results were reported as Gallic acid equivalents (GAE) per $100 \mathrm{~g}$ of powder. A standard curve (in duplicate) was prepared using different concentrations of Gallic acid: $0,8,16,24,32,41,49,57$ and $66 \mu \mathrm{g}$ adding solution equally as for sample problems and absorbance measured in the same manner as the reconstituted "aguamiel".

\subsubsection{Antioxidant Capacity (AC)}

The DPPH (1,1-diphenyl-2-picrylhydrazyl) method, developed by Brand-Williams, Cuvelier, \& Berset (1995) with some modifications (Cid-Ortega \& Guerrero-Beltrán, 2016), was used. $500 \mathrm{mg}$ of powder was dissolved with distilled water and made up to $10 \mathrm{~mL}$; then, $1 \mathrm{~mL}$ of this solution was taken and made up to $10 \mathrm{ml}$ with $99.5 \%$ ethanol. The solution was allowed to settle and then filtered through Whatman paper No. 4. $2000 \mu \mathrm{L}$ of the filtrate was taken and placed in test tubes (covered with aluminum foil), $2 \mathrm{ml}$ of DPPH solution (3.9 $\mathrm{mg}$ in 100 
$\mathrm{ml}$ of $99.5 \%$ ethanol) added, thoroughly mixed and allowed to stand for $45 \mathrm{~min}$ at room temperature $\left(22 \pm 1^{\circ} \mathrm{C}\right)$ in the dark. Absorbance was measured at $517 \mathrm{~nm}$ using a Cary $100 \mathrm{UV}$-Visible spectrophotometer (Varian Inc., Palo Alto, CA, USA). Results were expressed as Trolox ( $\mathrm{T}=$ 6-hydroxy-2,2,7,8-tetramethylchrom-2-carboxylic acid) equivalents per $100 \mathrm{~g}$ of powder. Separately, a standard curve (in duplicate) was prepared with different concentrations of T: 0, 7.3, 11.0, 14.6, 18.3, 22.0, 25.6, and $29.3 \mu \mathrm{g}$. Absorbance was read in the same manner as the reconstituted "aguamiel".

\subsection{Sensory Evaluation}

Fresh "aguamiel" and rehydrated powders were sensory evaluated using a nine-point hedonic scale (from 1 being "extremely dislike" to 9 being "extremely like") (Jones, Peryam, \& Thurstone, 1955) with a panel of 25 untrained judges (18-24 years old).

\subsection{Statistical Analysis}

Statistical analysis of the results was performed using an analysis of variance (ANOVA) with a significance level of 0.05 using the MINITAB software version 17. A Tukey comparison test was applied to establish differences within the averages of the variables evaluated.

\section{Results and Discussion}

\subsection{Powders}

\subsubsection{Physicochemical Characteristics}

Table 1 shows the physicochemical characteristics of fresh and reconstituted microencapsulated "aguamiel" powders with different concentrations of maltodextrin and Arabic gum $\left(\mathrm{P}_{1}, \mathrm{P}_{2}\right.$ and $\left.\mathrm{P}_{3}\right)$. The average moisture content (MC) of fresh "aguamiel" was $88.33 \pm 0.08 \%$ (w/v) and for reconstituted powders was $2.55 \pm 0.24 \%$ $(\mathrm{w} / \mathrm{v})$. The moisture content in food powders, being less than $7 \%$, can be considered a product that has a water reduced diffusion coefficient due to the dry matrix (Carrillo-Navas, González-Rodea, Cruz-Olivares, Barrera-Pichardo, Román-Guerrero, \& Pérez-Alonso, 2011). The water activity $\left(a_{w}\right)$ indicates the availability of free water in a food system, responsible for any physicochemical and biochemical reaction. In a food matrix to be microbiologically stable, values of $a_{w}$ must be less than 0.6. In "aguamiel" powders, the average $a_{w}$ was 0.34 \pm 0.02 ; thus, those powders might have a good stability during storage if they are suitably packaged. However, the deterioration in these types of powders could be due to chemical reactions induced by physical changes in the surroundings, but not due to microbial growth (Quek, Chok, \& Swedlund, 2007).

Table 1. Physicochemical characteristics of fresh "aguamiel" and reconstituted powders obtained by spray-drying ${ }^{1}$

\begin{tabular}{lcrrr}
\hline Variable & Fresh "Aguamiel" & \multicolumn{3}{c}{ Powders } \\
\cline { 3 - 5 } & & \multicolumn{1}{c}{$\mathrm{P}_{1}$} & \multicolumn{1}{c}{$\mathrm{P}_{3}$} \\
\hline Moisture content $(\%)$ & $88.33 \pm 0.08 \mathrm{a}$ & $2.58 \pm 0.16 \mathrm{~b}$ & $2.61 \pm 0.36 \mathrm{~b}$ & $2.43 \pm 0.18 \mathrm{~b}$ \\
$a_{\mathrm{w}}$ & $0.98 \pm 0.01 \mathrm{a}$ & $0.35 \pm 0.03 \mathrm{~b}$ & $0.34 \pm 0.02 \mathrm{~b}$ & $0.34 \pm 0.01 \mathrm{~b}$ \\
$\mathrm{~d}_{50}(\mu \mathrm{m})$ & - & $30.30 \pm 0.84 \mathrm{~b}$ & $30.89 \pm 0.81 \mathrm{~b}$ & $28.29 \pm 0.63 \mathrm{~b}$ \\
\hline
\end{tabular}

Values represent the mean \pm standard deviation $(\mathrm{n}=3)$. Values with different letters in the same row have significant differences ( $\mathrm{p} \leq 0.05$ ). ${ }^{1} \mathrm{P}_{1}, \mathrm{AM} / \mathrm{MD}, \mathrm{P}_{2}$, AM/AG/MD (AG:MD, 3:1), $\mathrm{P}_{3}$, AM/AG/MD (AG:MD, 1:3).

Carrillo-Navas, Guadarrama-Lezama, Cruz-Olivares, Báez-González, Bautista, \& Pérez-Alonso (2013) have investigated the stability conditions for the storage of powders of red bet juice encapsulated using Arabic gum. They pointed out that the stability of the encapsulated powders stored at $25^{\circ} \mathrm{C}$ above of the critical moisture content $(M C c=7.60)$ and critical water activity $\left(a_{w c}=0.595\right)$ could change the structure of the material; therefore, agglomeration, collapse and, or fissures may occur; consequently, powders with poor quality. The particle average size $\left(\mathrm{d}_{50}\right)$ of the powders was $29.84 \pm 1.4 \mu \mathrm{m}$. No statistically significant difference $(\mathrm{p}>0.05)$ was observed among particle size of the three powders obtained with different gums as carriers.

\subsubsection{Color}

The color values for the spray-dried powders are presented in Table 2 . The highest lightness value $\left(L^{*}\right)$ was shown by powder $\mathrm{P}_{1}(92.5433 \pm 0.85)$, tending to pure white, followed by powder $\mathrm{P}_{3}(87.99 \pm 0.05)$ and finally by powder $\mathrm{P}_{2}(83.18 \pm 1.00)$. All these values are mainly due to the color of the gums; hence, the higher the concentration of maltodextrin in the blend, the clearer the obtained powder since maltodextrin is almost white $\left(L^{*}=100=\right.$ white). The same was observed by A-Sun, Thumthanaruk, Lekhavat, \& Jumnongpon (2016) when 
evaluating the effect of the spray-drying conditions on the physical characteristics of coconut sugar. They pointed out that the addition of high concentrations of maltodextrin may cause a significant change in lightness $\left(L^{*}\right)$, increasing the value. In our study the greater value of the $a^{*}$ (red-green) color parameter was shown by powders $\mathrm{P}_{2}$ and $\mathrm{P}_{3}$. The values of $a^{*}$ of these two powders were between 1 and 2, indicating that the color was in the red-yellow color quadrant of the color space, confirmed by the values of the $b *$ color parameter. On the other hand, the value of the $a^{*}$ color parameter for powder $\mathrm{P}_{1}$ was in the green-yellow quadrant (the value for $a^{*}$ was negative). The highest value of the $b^{*}$ color parameter (yellow-blue) was observed in powder $\mathrm{P}_{2}(13.24 \pm 0.41)$. These values indicate that powders with the highest concentration of Arabic gum have a yellowish color. Due to the above, the hue of powder $P_{1}$ is located in the yellow-green section of the color space $\left(96.27 \pm 0.39^{\circ}=\right.$ $\left.180^{\circ}-83.73 \pm 0.39^{\circ}\right)$ (Baqueiro-Peña \& Guerrero-Beltrán, 2017). Color of powders $\mathrm{P}_{2}\left(86.01 \pm 0.17^{\circ}\right)$ and $\mathrm{P}_{3}$ $\left(89.38 \pm 0.09^{\circ}\right)$ are in the yellow-red section of the color space. In the case of purity, this was higher for $\mathrm{P}_{1}(5.00$ $\pm 0.06)$ followed by the powder $P_{3}(11.72 \pm 0.24)$ and finally by the powder $P_{2}(13.27 \pm 0.41)$.

Table 2. Effect of gums blend on color properties in spray-dried powders ${ }^{1}$

\begin{tabular}{llllll}
\hline Powder & $L^{*}$ & $a^{*}$ & $b^{*}$ & $H\left(^{\circ}\right)$ & $C$ \\
\hline $\mathrm{P}_{1}$ & $92.54 \pm 0.85 \mathrm{a}$ & $-0.55 \pm 0.04 \mathrm{~b}$ & $4.97 \pm 0.06 \mathrm{c}$ & $96.27 \pm 0.39 \mathrm{c}$ & $5.00 \pm 0.06 \mathrm{c}$ \\
$\mathrm{P}_{2}$ & $83.18 \pm 1.00 \mathrm{c}$ & $0.91 \pm 0.02 \mathrm{a}$ & $13.24 \pm 0.41 \mathrm{a}$ & $86.01 \pm 0.17 \mathrm{~b}$ & $13.27 \pm 0.41 \mathrm{a}$ \\
$\mathrm{P}_{3}$ & $87.99 \pm 0.05 \mathrm{~b}$ & $0.13 \pm 0.02 \mathrm{a}$ & $11.72 \pm 0.24 \mathrm{~b}$ & $89.38 \pm 0.09 \mathrm{a}$ & $11.72 \pm 0.24 \mathrm{~b}$ \\
\hline
\end{tabular}

Values represent the mean \pm standard deviation $(\mathrm{n}=5)$. Values with different letter in the same column show significant differences $(\mathrm{p} \leq 0.05) .{ }^{1} \mathrm{P}_{1}, \mathrm{AM} / \mathrm{MD}, \mathrm{P}_{2}$, AM/AG/MD (AG:MD, 3:1), $\mathrm{P}_{3}$, AM/AG/MD (AG:MD, 1:3).

\subsubsection{Microbial Counts}

The aerobic mesophilic bacteria (AMB) counts in fresh "aguamiel" were $(2.800 \pm 0.436) \times 10^{7} \mathrm{CFU} / \mathrm{mL}$. Figure 1 shows the AMB counts of the three powders obtained from fresh "aguamiel". It is clear that the initial AMB counts for each powder was different. A significant difference $(\mathrm{p} \leq 0.05)$ in AMB counts along the storage 60 days) was observed for the three powders; however, the final contents of AMB in all powders were similar to that of initial contents. Therefore, the observed differences might be due to experimental errors and not to the fact that the AMB counts were different throughout the storage. The overall average of AMB counts throughout the storage was 3,880 $\pm 705,2,200 \pm 187$, and 6,200 \pm 557 CFU/g for $\mathrm{P}_{1}, \mathrm{P}_{2}$ and $\mathrm{P}_{3}$ powders, respectively. The amount of AMB was not actually high, considering that it comes from fresh "aguamiel"; the AMB in powders can be considered as probiotic biomass (Nazzaro, Fratianni, Orlando, \& Coppola, 2012). In view of the fact that the inlet and outlet temperatures used in spray drying determine the viability of microorganisms, the AMB loads obtained were practically the same. Rodríguez-Huezo et al. (2007) used "aguamiel" as a "thermoprotector" and maltodextrin, among other gums, for encapsulating Bifidobacterium bifidum to improve its prebiotic activity. They used an inlet and outlet air temperature of 150 and $70^{\circ} \mathrm{C}$, respectively, in the spray-drying system. Colloids, such as maltodextrins, can perform as protectors of the encapsulated materials offering resistance to oxygen diffusion and improving the storage conditions (Cavalheiro, De Araújo, Da Silveira, Ragagnin, \& Martins, 2015).

\subsubsection{Total Phenolics Content (TPC)}

Table 3 shows the content of total phenolics for microencapsulated powders stored for 95 days at room temperature $\left(24 \pm 1^{\circ} \mathrm{C}\right)$. Regarding the type of powder, a significant difference was observed between them ( $\mathrm{p} \leq$ $0.05)$, both at the beginning and after 95 days of storage. According to the total global average, a big variability was observed when assessing the total phenolic content; however, no significant difference $(p>0.05)$ was observed in the total phenolic compounds content throughout storage. Pérez-Alonso et al. (2015) studied the stability of phenolics of Opuntia oligacantha Forst (xoconostle) encapsulated with Arabic gum and maltodextrin (1:1 ratio) using "aguamiel" as a thermoprotective carrier. They reported that, regardless of the drying temperature $\left(150^{\circ} \mathrm{C}\right.$ and $\left.160^{\circ} \mathrm{C}\right)$ phenolic compounds were stable for more than 49 months at $25^{\circ} \mathrm{C}$. 


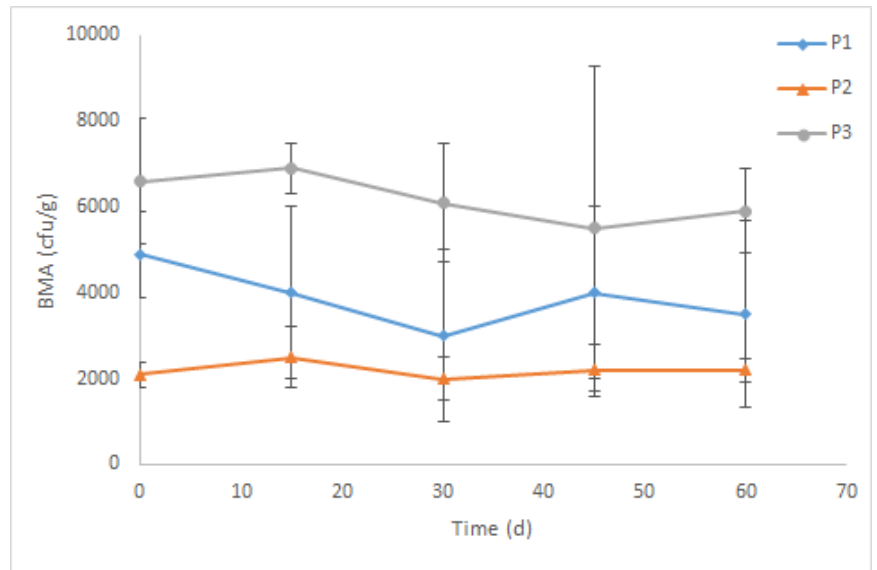

Figure 1. Counts of aerobic mesophilic bacteria (AMB) in microencapsulated "aguamiel" powders stored at $24 \pm$ $1^{\circ} \mathrm{C}$. Values represent the mean \pm standard deviation $(\mathrm{n}=3)$

Table 3. Effect of storage time and gum blends on total phenolics content (mg equivalents of Gallic acid/100 g powder) in "aguamiel" powders"

\begin{tabular}{llll}
\hline Blend of gums & \multicolumn{3}{c}{ Time (day) } \\
\cline { 2 - 4 } & 0 & 95 & Average $^{2}$ \\
\hline $\mathrm{P}_{1}$ & $307.41 \pm 27.07 \mathrm{a}$ & $216.01 \pm 20.64 \mathrm{a}$ & $212.40 \pm 68.22 \mathrm{a}$ \\
$\mathrm{P}_{2}$ & $444.70 \pm 1.92 \mathrm{~b}$ & $438.90 \pm 18.61 \mathrm{~b}$ & $350.51 \pm 145.0 \mathrm{~b}$ \\
$\mathrm{P}_{3}$ & $326.04 \pm 45.73 \mathrm{a}$ & $322.02 \pm 9.16 \mathrm{c}$ & $266.25 \pm 89.93 \mathrm{ab}$ \\
\hline
\end{tabular}

Values represent the mean \pm standard deviation $(n=5)$. Values with different letters within columns are significantly different $(\mathrm{p} \leq 0.05)$. There was no significant difference $(\mathrm{p} \leq 0.05)$ within storage times. ${ }^{1} \mathrm{P}_{1}$, AM/MD, $\mathrm{P}_{2}$, AM/AG/MD (AG:MD, 3:1), $\mathrm{P}_{3}$, AM/AG/MD (AG:MD, 1:3). ${ }^{2}$ Represents the total global average of TPC along the storage ( 0 to 95 days).

\subsubsection{Antioxidant Capacity (AC)}

The antioxidant capacity of "aguamiel" powders obtained with different encapsulants is shown in Table 4. No significant differences were observed $(\mathrm{p}>0.05)$ along the storage time (95 days); however, significant differences were observed $(\mathrm{p} \leq 0.05)$ within the three powders; this was very likely due to the type of gums blend used to encapsulate. Pitalua, Jiménez, Vernon-Carter, \& Beristain (2010) obtained spray-dried beet juice powder using Arabic gum; they evaluated the stability of antioxidants during storage to different water activity environments $(0.110,0.326,5.21,0.748$, and 0.898$)$. The authors reported that the antioxidant activity was higher at higher $a_{w}$ values $(0.748$ and 0.898$)$; however, it should be recalled that high water activities are not recommended for storing food powders because they tends to collapse and may undergo changes because of the high amount of water in the system. On the other hand, powders stored at water activities less than 0.521 presented better stability since no caking or liquefaction was observed. It is important to emphasize that the water activity during the storage of powders is of paramount importance since $a_{w}$ is the best indicator of changes that powders can undergo during storage: the adsorption of water greatly influences its stability as well as dryness since crystallization may occur.

Table 4. Effect of storage time and gums blends on the antioxidant capacity (mg equivalents of Trolox/100 $\mathrm{g}$ of powder) in "aguamiel" powders ${ }^{1}$

\begin{tabular}{llll}
\hline Blend of gums & \multicolumn{3}{c}{ Time (day) } \\
\cline { 2 - 4 } & 0 & 95 & Average $^{2}$ \\
\hline $\mathrm{P}_{1}$ & $1374.82 \pm 27.71 \mathrm{a}$ & $1159.34 \pm 23.60 \mathrm{a}$ & $1207.13 \pm 104.17 \mathrm{a}$ \\
$\mathrm{P}_{2}$ & $1154.99 \pm 1.81 \mathrm{~b}$ & $1023.10 \pm 13.42 \mathrm{~b}$ & $1172.17 \pm 153.60 \mathrm{a}$ \\
$\mathrm{P}_{3}$ & $1150.85 \pm 15.40 \mathrm{~b}$ & $1196.34 \pm 0.00 \mathrm{a}$ & $1183.34 \pm 62.00 \mathrm{a}$ \\
\hline
\end{tabular}

Values represent the mean \pm standard deviation $(\mathrm{n}=5)$. Values with different letters within columns are significantly different $(\mathrm{p} \leq 0.05)$. There was no significant difference $(\mathrm{p} \leq 0.05)$ within storage times. $\mathrm{P}_{1}$, AM/MD, $\mathrm{P}_{2}$, AM/AG/MD (AG:MD, 3:1), $\mathrm{P}_{3}$, AM/AG/MD (AG:MD, 1:3). ${ }^{2}$ Represents the total global average of TPC along the storage (0 to 95 days). 


\section{2 "Aguamiel" and Rehydrated Powders}

\subsubsection{Physicochemical Characteristics}

The physicochemical characteristics of fresh "aguamiel" and rehydrated powders are shown in Table 5. In general, most of the physicochemical characteristics of "aguamiel" and rehydrated powders showed no significant differences ( $p>0.05)$. The moisture content and total soluble solids in fresh "aguamiel" was similar to that reported by Muñíz-Márquez et al., (2013) for Agave americana cv. "cenizo" (86.90\%) and cv. "manso" $\left(11.44^{\circ} \mathrm{Brix}\right)$. The density obtained in our study for fresh "aguamiel" of Agave salmiana was lower than that obtained by the same author for Agave americana $(1.26 \mathrm{~g} / \mathrm{mL})$. According to the Mexican Standard Norm number NMX-V-022-1972 (DGN, 1972), fresh "aguamiel" used in this work can be classified as aguamiel Type II, since it had a pH of 4.00 and its content of lactic acid was less than $4 \mathrm{mg} / 100 \mathrm{~mL}$. The viscosity of fresh "aguamiel" was statistically similar $(\mathrm{p}>0.05)$ to viscosities of rehydrated powders $\mathrm{P}_{1}$ and $\mathrm{P}_{3}$ but different $(\mathrm{p} \leq$ $0.05)$ than that for powder $P_{2}(2.12 \pm 0.08)$. The water activity was statistically similar for fresh "aguamiel" and the three rehydrated powders. The amount of ash in fresh "aguamiel" $(0.62 \pm 0.03 \mathrm{~g} / 00 \mathrm{~mL})$ was higher than for the amount reported by Muñíz-Márquez et al. (2013) $(0.53 \mathrm{~g} / 100 \mathrm{~mL})$. Bautista and Arias (2008), in a study carried out in aguamiel of Agave americana L., reported an ash content of $0.23 \mathrm{~g} / 100 \mathrm{~mL}$, this value for ash was similar to that obtained for the rehydrated powder $\mathrm{P}_{1}(0.25 \pm 0.03 \mathrm{~g} / 100 \mathrm{~mL})$ and the average for the three rehydrated powders $(0.286 \mathrm{~g} / 100 \mathrm{~mL})$. The amount of ash may be due to the season of harvesting, the ground where Agaves are planted and the species and variety.

The physicochemical composition of aguamiel does not have large variations regarding the agave variety (Muñíz-Márquez et al., 2013); however, the variation in the composition might be due to climatic factors, age of the plant in its production time (Flores, Coyotl, Hernández, Velásquez, \& Hernández, 2006).

Table 5. Physicochemical characteristics of fresh "aguamiel" and rehydrated powders 1

\begin{tabular}{lllll}
\hline Variable & Fresh "Aguamiel" & \multicolumn{3}{c}{ Rehydrated powders } \\
\cline { 3 - 5 } & & $\mathrm{P}_{1}$ & $\mathrm{P}_{2}$ & $\mathrm{P}_{3}$ \\
\hline Moisture content $(\%)$ & $88.33 \pm 0.08 \mathrm{a}$ & $88.17 \pm 0.00 \mathrm{~b}$ & $88.05 \pm 0.00 \mathrm{~b}$ & $88.19 \pm 0.00 \mathrm{~b}$ \\
TSS $\left({ }^{\circ}\right.$ Brix $)$ & $11.5 \pm 0.10 \mathrm{a}$ & $11.5 \pm 0.06 \mathrm{a}$ & $11.5 \pm 0.12 \mathrm{a}$ & $11.5 \pm 0.06 \mathrm{a}$ \\
$\mathrm{pH}$ & $4.0 \pm 0.06 \mathrm{a}$ & $4.18 \pm 4.18 \mathrm{a}$ & $4.06 \pm 0.02 \mathrm{a}$ & $4.16 \pm 0.01 \mathrm{a}$ \\
Acidity $(\%)^{2}$ & $0.13 \pm 0.00 \mathrm{~b}$ & $0.11 \pm 0.00 \mathrm{a}$ & $0.12 \pm 0.00 \mathrm{a}$ & $0.11 \pm 0.00 \mathrm{a}$ \\
$a_{\mathrm{w}}$ & $0.980 \pm 0.011 \mathrm{a}$ & $0.981 \pm 0.001 \mathrm{a}$ & $0.982 \pm 0.001 \mathrm{a}$ & $0.981 \pm 0.001 \mathrm{a}$ \\
Density $(\mathrm{g} / \mathrm{mL})$ & $1.12 \pm 0.05 \mathrm{a}$ & $1.12 \pm 0.06 \mathrm{a}$ & $1.10 \pm 0.06 \mathrm{a}$ & $1.05 \pm 0.06 \mathrm{a}$ \\
Viscosity $(\mathrm{Cp})$ & $1.74 \pm 0.14 \mathrm{~b}$ & $1.83 \pm 0.09 \mathrm{~b}$ & $2.12 \pm 0.08 \mathrm{a}$ & $1.85 \pm 0.10 \mathrm{~b}$ \\
Ash $(\mathrm{g} / 100 \mathrm{~mL})$ & $0.62 \pm 0.03 \mathrm{a}$ & $0.25 \pm 0.03 \mathrm{c}$ & $0.33 \pm 0.04 \mathrm{~b}$ & $0.28 \pm 0.01 \mathrm{c}$ \\
\hline
\end{tabular}

Values represent the mean \pm standard deviation $(\mathrm{n}=5)$. Values with different letter in the same column show significant differences $(\mathrm{p} \leq 0.05) .{ }^{1} \mathrm{P}_{1}, \mathrm{AM} / \mathrm{MD}, \mathrm{P}_{2}$, AM/AG/MD (AG:MD, 3:1), $\mathrm{P}_{3}$, AM/AG/MD (AG:MD, 1:3). ${ }^{2}$ Lactic acid.

\subsubsection{Color}

Table 6 shows the color parameters of fresh "aguamiel" and rehydrated powders. The luminosity value of fresh aguamiel was similar to the value for the powder $P_{2}$ but smaller $(p<0.05)$ than for powders $P_{1}$ and $P_{3}$ indicating that those are lighter than the other two powders. In the case of the $a^{*}$ (red-green) color parameter, the four values are in the red-yellow segment of the color space; the value for fresh "aguamiel" was greater $(\mathrm{p}<0.05)$ than values of the rehydrated powders. The $b^{*}$ (yellow-blue) value of the rehydrated powder $\mathrm{P}_{2}$ showed the greater tendency toward yellow; this may be probably due to the fact that Arabic gum is yellowish. The value of $b^{*}$ of the powder $\mathrm{P}_{1}$ showed the lowest value (7.85) which could be due to the ivory pale color of the maltodextrin. The tone of all aguamiel products are in the red-yellow segment of the color space since the angles are located in this segment. The hue values of fresh "aguamiel" and the rehydrated powders did not show significant differences $(\mathrm{p}>0.05)$. In the case of purity, this was higher for $\mathrm{P}_{2}(21.88 \pm 0.09)$ (yellowish due to Arabic gum), followed by $\mathrm{P}_{3}(13.66 \pm 0.46)$ (yellowish), fresh "aguamiel" (13.27 \pm 0.38 (yellowish) and finally by the rehydrated powder $\mathrm{P}_{1}(7.93 \pm 0.11)$ (pale yellowish); the bigger the amount of AG, the higher the purity (yellow) of the rehydrated powder. 
Table 6. Color parameters of fresh "aguamiel" and rehydrated powders ${ }^{1}$

\begin{tabular}{llllll}
\hline Powder & $L^{*}$ & $a^{*}$ & $b^{*}$ & $H\left(^{\circ}\right)$ & $C$ \\
\hline Fresh & $48.03 \pm 0.06 \mathrm{c}$ & $4.73 \pm 0.38 \mathrm{a}$ & $12.40 \pm 0.41 \mathrm{c}$ & $69.11 \pm 1.74 \mathrm{a}$ & $13.27 \pm 0.38 \mathrm{~b}$ \\
$\mathrm{P}_{1}$ rehyd & $59.13 \pm 0.05 \mathrm{a}$ & $1.09 \pm 0.02 \mathrm{c}$ & $7.85 \pm 0.11 \mathrm{~d}$ & $82.12 \pm 0.13 \mathrm{a}$ & $7.93 \pm 0.11 \mathrm{c}$ \\
$\mathrm{P}_{2}$ rehyd & $48.38 \pm 1.33 \mathrm{c}$ & $1.75 \pm 0.05 \mathrm{~b}$ & $21.81 \pm 0.08 \mathrm{a}$ & $85.41 \pm 0.11 \mathrm{a}$ & $21.88 \pm 0.09 \mathrm{a}$ \\
$\mathrm{P}_{3}$ rehyd & $52.71 \pm 0.60 \mathrm{~b}$ & $1.13 \pm 0.11 \mathrm{c}$ & $13.60 \pm 0.45 \mathrm{~b}$ & $85.26 \pm 0.33 \mathrm{a}$ & $13.66 \pm 0.46 \mathrm{~b}$ \\
\hline
\end{tabular}

Values represent the mean \pm standard deviation $(n=5)$. Values with different letter in the same column show significant differences ( $\mathrm{p}<0.05$ ). ${ }^{1} \mathrm{P}_{1}, \mathrm{AM} / \mathrm{MD}, \mathrm{P}_{2}$, AM/AG/MD (AG:MD, 3:1), $\mathrm{P}_{3}, \mathrm{AM} / \mathrm{AG} / \mathrm{MD}$ (AG:MD, 1:3).

\subsubsection{Sensory Characteristics}

The results of sensory evaluation of fresh "aguamiel" and rehydrated powders $\mathrm{P}_{1}, \mathrm{P}_{2}$ and $\mathrm{P}_{3}$ were $6.08 \pm 1.93$, $5.64 \pm 2.18,6.20 \pm 1.91$ and $6.72 \pm 1.06$, respectively. According to these results, powder $\mathrm{P}_{3}$ (maltodextrin-Arabic gum 1:3) had the highest overall acceptability followed by powder $\mathrm{P}_{1}$ (maltodextrin) and $\mathrm{P}_{2}$ (Arabic gum-maltodextrin 3:1); however, no significant differences $(\mathrm{p}>0.05)$ were observed among fresh "aguamiel" and rehydrated powders. The judges commented that they perceived a flavor of "grass", characteristic of fresh "aguamiel". The $\mathrm{P}_{3}$ rehydrated powder was more pleasant to judges.

\section{Conclusions}

Spray-drying of the "aguamiel", using the blend of Arabic gum:maltodextrin in a ratio 1:3 delivered a stable powder with sensory properties similar to those of fresh "aguamiel". According to the physicochemical and sensory characteristics of the three powders, they can be considered stable and give greater shelf-life to the fresh "aguamiel". Therefore, "aguamiel" powder is an alternative for sweeteners; it can be used as a direct sweetener for foods or drinks or to be added to processed foods or to home-made products.

\section{Acknowledgments}

The authors wish to thank the "Programa para el Desarrollo Profesional Docente" for providing financial support through project PRODEP No. DSA/103.5/15/6886 "Apoyo a la Reincorporación de Exbecarios PROMEP" to M.C. Alfredo Salvador Castro-Díaz, professor of the "Universidad Tecnológica de Tecamachalco (UTTECAM)".

\section{References}

AOAC. (1995). Official Methods of Analysis. Association of Analytical Chemists. Washington D.C., USA.

AOAC. (2000). Official Methods of Analysis. Association of Analytical Chemists. Washington D.C., USA.

Alfaro, G., Legaria, P. \& Rodríguez, J. (2007). Genetic diversity in populations of pulquero agaves (Agave spp.) in northeastern Mexico State. Revista Fitotecnia Mexicana, 30(1), 1-12.

A-Sun, K., Thumthanaruk, B., Lekhavat, S., \& Jumnongpon, R. (2016). Effect of spray drying conditions on physical characteristics of coconut sugar powder (Short Communication). International Food Research Journal, 23(3), 1315-1319.

Baqueiro-Peña, I., \& Guerrero-Beltrán, J. Á. (2017). Physicochemical and antioxidant characteristics of Justicia spicigera. Food Chemistry, 218, 305-312. https://doi.org/10.1016/j.foodchem.2016.09.078

Bautista, N. D., \& Arias, G. C. (2008). Estudio químico bromatológico de aguamiel de Agave americana (maguey). Ciencia e Investigación, 11(2), 46-51.

Bernstein, A., \& Zapata, P. (2015). Encapsulation of red cabbage (Brassica oleracea L. var. Capitata L. F. rubra) anthocyanins by spray drying using different encapsulating agents. Brazilian Archives of Biology and Technology, 58(69), 1-6. https://doi.org/10.1590/S1516-89132015060226

Brand-Williams, W., Cuvelier, M. E., \& Berset, C. (1995). Use of free radical method to evaluate antioxidant activity. Lebensmittel-Wissenschaft and Technologie, 28, 25-30. https://doi.org/10.1016/S0023-6438(95)80008-5

Carrillo-Navas, H., Guadarrama-Lezama, A. Y., Cruz-Olivares, J., Báez-González, J. G., Bautista, V. M., \& Pérez-Alonso, C. (2013). Determinación de las condiciones críticas de estabilidad de jugo de betabel microencapsulado mediante secado por aspersión. Paper presented at the Fiftieth "Congreso Internacional de Ciencia y Tecnología de Alimentos." Universidad de Colima. Colima, Colima. Abstract retrieved from https://ciatej.repositorioinstitucional.mx/jspui/bitstream/1023/136/1/MEMORIAS\%20Trabajo\%203\%20Infl uencia\%20de\%201a\%20fuerza\%20i\%C3\%B3nica\%20y\%20Tris.pdf 
Carrillo-Navas, H., González-Rodea, D. A., Cruz-Olivares, J., Barrera-Pichardo, J. F., Román-Guerrero, A., \& Pérez-Alonso, C. (2011). Storage Stability and Physicochemical properties of passion fruit juice microcapsules by spray drying. Revista Mexicana de Ingeniería Química, 10(3), 421-430.

Cavalheiro, C. P., De Araújo, M., Da Silveira, M. F., Ragagnin, C., \& Martins, L. L. (2015). Encapsulation: an alternative for application of probiotic microorganisms in thermally processed foods. Centro de Ciências Naturais e Exatas (CCNE), UFSM, Brazil, 37, 65-74. https://doi.org/10.5902/2179- 460X19717

Cenvantes-Contreras, M. (2008). Caracterización microbiológica del pulque y cuantificación de su contenido de etanol mediante espectroscopia Raman. Sociedad Mexicana de Ciencia y Tecnología de Superficies y Materiales, 20(3), 1-5.

Cid-Ortega, S., \& Guerrero-Beltrán, J. Á. (2016). Antioxidant and physicochemical properties of Hibiscus sabdariffa extracts from two particle sizes. Journal of Food Research, 5(2), 98-109. https://doi.org/10.5539/jfr.v5n2p98

DGN. (1972). Norma Mexicana NMX-V-022-1972. Aguamiel. Hidromiel. Normas Mexicanas. Dirección General de Normas. Mexico, D.F.

DGN. (1978a). Norma Mexicana NMX-F-317-S-1978. Determinación de pH en alimentos. Normas Mexicanas. Dirección General de Normas. Mexico, D.F.

DGN. (1978b). Norma Mexicana NMX-F-317-S-1978. Determinación de cenizas en alimentos. Normas Mexicanas. Dirección General de Normas. Mexico, D.F.

Estrada-Godinal, A., Cruz-Guerrero, L. A., Lappe, P., Ulloa, P., Garcia-Garibay, L. M., \& Gómez-Ruiz, L. (2001). Isolation and identification of killer yeasts from Agave sap (aguamiel) and pulque. World Journal of Microbiology and Biotechnology, 17, 557-560. https://doi.org/10.1023/A:1012210106203

Flores, M. A., Coyotl, H. J., Hernández, T. M., Velásquez, J. L., \& Hernández, A. (2006). Gestión de calidad de una miel obtenida a partir de aguamiel de maguey pulquero. Paper presented at the Forth International and Fiftieth National "Congress de Ingeniería Bioquímica.” Morelia, Michoacán, México. http://www.informatica.sip.ipn.mx/colmex/congresos/morelia/MEMORIAS\%202006/TRABAJOS\%20EN \%20EXTENSO/E-426.pdf

Guerrero-Beltrán, J. A., Jiménez-Munguía, M. T., Welti-Chanes, J., \& Barbosa-Cánovas, G. V. (2009). Particle size distribution functions for food powders. In M. E. Sosa-Morales \& J. F. Vélez-Ruiz (Eds.), Food Processing and Engineering Topics (pp. 59-85). New York, USA: Nova Science Publishers, Inc.

Guillot, D., \& Deer, P. (2008). Una nueva cita de la especie Agave salmiana Otto Ex Salm-Dyck en la comunidad valenciana. Bouteloua, 2, 19-23.

Jones, L. V., Peryam, D. R., \& Thurstone, L. L. (1955). Development of a scale for measuring soldiers' food preferences. Food Research, 20, 512-520. https://doi.org/10.1111/j.1365-2621.1955.tb16862.x

Lappe-Oliveras, P., Moreno-Terrazas, R., Arrizón-Gaviño, J., Herrera-Suárez, T., García-Mendoza, A., \& Gschaedler-Mathis, A. (2008). Yeasts associated with the production of Mexican alcoholic nondistilled and distilled Agave beverages. FEMS Yeast Research, 8(7), 1037-1052. https://doi.org/10.1111/j.1567-1364.2008.00430.x

Li, R., Roos, Y., \& Miao, S. (2017). Characterization of mechanical and encapsulation properties of lactose maltodextrin WPI matrix. Food Hidrocolloids, 63, 149-159. https://doi.org/10.1016/j.foodhyd.2016.08.033

Martínez-Morales, R. \& Meyer, S. (1985). A demographic study of maguey verde (Agave salmiana ssp. Crassispina) under conditions of intense utilization. Journal Desert Plants, 7(2), 61-66.

Muñíz-Márquez, D., Rodríguez-Jasso, R., Rodríguez-Herrera, R., Contreras-Esquivel, J., \& Aguilar-González, C. (2013). Mexicana artisanal production of aguamiel: A traditional Mexican beverage. Revista Científica de la Universidad Autónoma de Coahuila, 5(10), 12-19.

Nazzaro, F., Fratianni, F., Orlando, P., \& Coppola, R. (2012). Biochemical traits, survival and biological properties of the probiotic Lactobacillus plantarum grown in the presence of prebiotic inulin and pectin as energy source. Pharmaceuticals, 5, 481-492. https://doi.org/10.3390/ph5050481

Ortiz-Basurto, R. I., Pourcelly, G., Doco, T., Williams, P., Dornier, M., \& Belleville, M, P. (2008). Analysis of the main components of the aguamiel produced by the maguey-pulquero (Agave mapisaga) throughout the harvest period. Agricultural and Food Chemistry, 56(10), 3682-3687. https://doi.org/10.1021/jf072767h 
Parra, L., A., Del Villar, P., \& Prieto, A. (2010). Extracción de fibras de agave para elaborar papel y artesanía. Acta Universitaria, 20(3), 77-83.

Pérez-Alonso, C., Campos-Montiel, R., Morales-Luna, E., Reyes-Munguia A., Aguirre-Alvarez \& Pimentel-Gonzalez, D. (2015). Stabillization of phenolic compounds from Opuntia oligacantha Forst. Revista Mexicana de Ingeniería Química, 14(3), 5779-588.

Pitalua, E., Jiménez, M., Vernon-Carter, E. J., \& Beristain, C. I. (2010). Antioxidative activity of microcapsules with beetroot juice using gum Arabic as wall material. Food and Bioproducts Processing, 88, 253-258. https://doi.org/10.1016/j.fbp.2010.01.002

Quek, S. Y., Chok, N. K., \& Swedlund, P. (2007). The physicochemical properties of spray-dried watermelon powders. Chemical Engineering and Processing, 46, 386-392. https://doi.org/10.1016/j.cep.2006.06.020

Rodríguez-Hueso, M., Durán-Lugo, R., Prado-Barragána, L., Cruz-Sosa, F., Lobato-Calleros, Calvares-Ramírez, J., \& Vernon-Carter, E. (2007). Pre-selection of protective colloids for enhanced viability of Bifidobacterium bifidum following spray-drying and storage, and evaluation of aguamiel as thermoprotective prebiotic. Food Research International, 40, 1299-1306. https://doi.org/10.1016/j.foodres.2007.09.001

Shmit, A., Castillo, F., Lazcano, D., Rojas, A., Núñez, Y., \& Valdés, A. (2014). Bioetanol a partir del maguey (Agave americana) y su prospectiva en México. Revista de Ciencia e Ingeniería del Instituto Tecnológico Superior de Coatzacoalcos, 1, 75-81.

Singleton, V. L., \& Rossi, J. A. (1965). Colorimetry of total phenolics with phosphomolybdic-phosphotungstic acid reagents. American Journal of Enology and Viticulture, 16(3), 144-158.

Uddin, M., Hawlader, N. \& Zhu, H. (2001). Microencapsulation of ascorbic acid: effect of process variables on product characteristics. Journal of Microencapsulation, 18(2), 199-209. https://doi.org/10.1080/02652040010000352

\section{Copyrights}

Copyright for this article is retained by the author(s), with first publication rights granted to the journal.

This is an open-access article distributed under the terms and conditions of the Creative Commons Attribution license (http://creativecommons.org/licenses/by/4.0/). 